the wires of the revolving cylinder, the revolution of the latter causes a powerful current to pass into the electromagnetic coils, this again inducing a still more powerful current in the wires of the cylindrical armature. The iron core of the cylindrical armature being very close to the poles of the electro-magnets, becomes itself an intensely powerful transverse magnet of opposite polarity to the electro-magnet. The cylinder of wire thus revolves in a very intense magnetic field.

These electrical currents are collected on two metal rollers or brushes, so that at two points diametrically opposite the single sectors pass under the rollers or biushes with elastic pressure giving up to them their electrical charge.

A sight increase of speed in the rotation of the wire cr linder is followed by a considerable increase of current, but as the current increases, so does the resistance to rotation; and this very rapidly. In addition to this heat is developed to such an extent, that care must be taken not to exceed a certain limit, otherwise, the insulation of the coils would be destroyed. Were it not for this drawback almost any amount of current might be produced with suitable driving power.

As the external resistance affects the strength of the current the speed must be varied accordingly, being greater as the external resistance is greater and vice versa. With an electric lamp in a circuit of small resistance, if the machine is intended to work continuously, the revolutions of the wire cylinder per minute should not exceed 370 to 380 . The temperature of the machine will then be at a maximum in about three hours ; and during work will remain constant. At this speed the driving power is about eight indicated horse-power. While the intensity of the light, unaided by reflector or lens, has been shown by various photometers to be equal to 14,000 normal English candles. A more intense electric light cannot be obtained as any increase in the current splits up even the best carbon.

The conducting wires from the machine to the lamp should be of copper, offering very litule resistance and at the same time possessing a high electrical conductivity. If the lengths of the two wires do not together exceed fifty-five yards, then a wire of O'I 57 inches diameter, and of high conductivity will suffice. For longer distances it is advisable to use a strand of larger diameter.

Increased speed will of course compensate for decrease of current due to a too great external resistance, but this can be done only at the expense of increased motive power.

The lamp used with the machine is regulated without clockwork, as the employment of the latter has not only been a source of numerons failures and difficulties, but is liable to disarrangement upon the least rough usage. The lamp of itself regulates the carbon poinis, keeping them at a uniform distance, and thus a perfectly steady light is produced.

For concentration either a parabolic reflector or a Fiesnel dioptric lens may be used.

For transportation the Dynamo-electric Light Apparatus is mounted on a waggon, with steam-engine, the whole weighing 4,960lbs. The combination has proved very serviceable on account of its lightness and compactness.

\section{THE ETHNOLOGY OF THE PAPUANS OF MACLAY COAST, NEW GUINEA 1} ITH regard to the villages and dwellings. So thickly
is the coast of Astrolabe Gulf covered whith vegetation that no houses are visible to anyone on shipboard, the only signs of habitation being perhaps columns of smoke. If, however, more careful observation be made with a telescope, separate groups of cocoa nut palms will be noticed.
If a landing be effected near one such group, a pirogice, or canoe, will probably be seen drawn up on the shore, or else corcealed in the jungle, and a path will be found leading through the wood to an open clearing, where stand huts overshadowed by bananas and cocoa-nut palms. Viewed from the side, one such hut seems almost wholly to consist of roof, as the side walls rise scarcely half a yard above the ground. A semi-circular eave-like projection frequently stands out over the doorway. Close in the neighbourhood of nearly every hut there stands upon four legs the barla, a kind of table or bench, which serves as the eating and resting-place of the men. Upon this, when the meal is ready, the host and his guests are seated, so that they can take their meal without fear of molestation from pigs or dogs. When the dishes are cleared away the Papuan takes his siesta upon the barla, which now serves as a kind of divan. The women on no account use the barla, but take their meals upon the ground. A village consists of several groups of huts (each group having a particular name) which stand around an open clearing, and communicate through narrow paths. The houses do not stand upon piles, ${ }^{1}$ and are for the most part small and dark, though well and strongly built; the roofs in particular, which do not have a flatly.inclined surface, but bul ze outside in order that the rain may be the easier carried off. The walls are made either of bamboo or of the stalks of sago-palm leaves. The door is raised generally about half a yard above the ground, to prevent the ingress of dogs and pigs.

There can generally be distinguished three kinds of huts-those of single prople, those of families, and the buambramra, which is usuilly only used by men, being intended for the youths of the village, and any chance guest. Here will be remarked the baroem, a kind of gong, which plays so important a part in the life of the Papuans. It resembles a thick-sided boat resting upon two trestles, and on the middle of the outer side may be seen a smooth, much-worn patch, the place where it is hit with a very thick stick, by which is produced a dull but loud tone, which has been heard on the coast at as great a distance as five or six miles. All important events, e.g. the presence of an enemy, a death, or a feast, are by this instrument heralded to the neighbouring villages, the quality of the news being signified by the varying loudness of the tones produced, and the length of the pauses between each."

It is a most extraordinary fact that all the people of the coast here have no means at all of making fire; wherefore they are obliged always and everywhere to carry a live coal with them, be it either to kindle a fire in a plantation, or, when on a long tour in the mountains, to relight their cigars, which, being wrapped in green leaves, are always going out. On their sea voyages they have generally a live coal at the bottom of the boat, in a broken pot partly filled with earth. Those who remain behind in the villages never forget to look after the fire, and even in the night a small fire is kindled under the sleeping-places, which partly makes up for scanty clothing. The warmth penetrates, togetber with smoke, through the insterstices of the bamboo bedstead, ${ }^{3}$ so that onehalf of the sleeper's body is warned, in fact roasted, while the other half is frozen. They are often obliged to get up in the night to see after the fire. The mountain people are rot obliged thus to tend, like the priestesses of Vesta, an eternal flame, but understand how to kindle fire anew, and by the following method, A piece of very dry wood, which they term 1lol, is split with a stone axe in such a manner that each half is not quite separated from the other. Into the fissure a strong cord, a split liana,

I The houses of all Malays, whether on the coast or in the mountains, always are built upon piles sometimes nine or ten feet long. - J. C $\mathrm{G}$. 2 A similar instrument is figured in Schweinfurvb's "Heart of Africa," as in use by the Niam-Niam tribe.-J. C. G.

3 'This is probably the equivalent of the bali-bali of the Malays, a frame of split bamboo, raised slightly from the ground. -J C. G. 
in fact, is introduced, and, after that the piece of wood has been firmly pressed against the ground by the foot or knee, is put into a continually increasing frictional movement until some dry cocoa-nut bark fibre, previously placed beneath, takes fire. This is a very tedious proceeding, as it lasts well-nigh half an hour. The aborigines of the coast have repeatedly told Maclay that they are frequently obliged to go to other villages to procure fire when by chance the fires in all the huts of a village have gone out.

The Papuans pass most of their time outside their huts, these latter serving principally as shelter during the night, or in bad weather. To the tie-beam of the hut a cord is fastened, from which hangs a memu, i.e. a stick with several hooks. In front of the stick a portion of the covering of the base of the leaf of the sago palm is so arranged that the cord passes through the middle of the same. To the hooks are hung various articles of food wrapped up in leaves. This arrangement serves to keep off the mice, which would otherwise make away with everything eatable in the night. Beyond a pair of spears, a few arrows, and other implements of the chase, there is nothing in the way of furniture in the hut of the Papuan. It would be difficult, in fact, "to find a human habitation more meagrely furnished. It is the custom to preserve some portion, e.g. the lower jaw, of every animal which has been eaten at feasts. These sonvenirs are hung aroulid the walls of the large common hut-bucmbrantre.

The plantations, or gardens, of the Papuans are seldom laid out near the huts, but for the sake of security are hidden in the junsle. A clearing is made by cutting down the undervood, and, after it has been dried in the sun, it is set on fire. The space thus prepared is then surrounded by a kind of hedge consisting of two rows of a kind of sugar-cane (Sacinarum spontaneun), which soon takes root, the opposite stems being fastened together with lianas, and the intervening space between the rows filled with rough-hewn logs. In less than a month's time a new plantation is put in full order and planted with bananas, sugar-cane, and the Collocasia and Dioscorea. The tools which are used for this purpose are very simple, being the wdja, a strong stick about two yards in length, and sharpened at one end-the implement of the men; and the $2 a^{2} j a-s a b$, which is used by the women, a kind of small spade. The Papuans have throughout the year a rotation of fruit and vegetables. Every day the women go forth to fetch from the plantations what is necessary for the same evening and the following morning. The coast people have the most property in cultivated land, while the islanders are chiefly employed in the manufacture of pots, dishes, and canoes.

Among the Papuans of Maclay Coast there exists neither trade nor a regular system of barter. If, for instance, the coast people visit their neighbours or the people of the hills, or the islanders, they bring with them as a present all the superfluous articles which they possess, and on their departure receive as presents productions of the village which they have visited. Maclay has never seen one single present given or demanded in return for an equivalent gift.

Not many villages are in possession of pirogues (canoes), because most of those on the coast are situated in the neighbourhood of a surf so strong as to make landing impossible. The canoes are hewn out of a single treetrunk, and have an outrigger (Aussengestell), and are manned by two rowers. The inhabitants, however, of Bili-Bili and of the "Archipelago of Contentment," build larger canoes, provided with two masts, "raking" one fore, the other aft. In these canoes the aborigines can sail with the most unfavourable winds. The large sail consists of a pandanus ${ }^{1}$ mat, and split bamboo and lianas serve as sheets and shrouds. The anchor is a piece of a tree-trunk, of which four or five branches encircling it, after being cut short and sharpened to a point, serve as the "flukes," and is weighted by means of a number of stones s.ttached to the shank by a sort of basket-work. Neither the coast people nor the inhabitants of the hills undertake voyages of any considerable extent.

With a few words on the daily life of the Papuans this article must be brought to a close. The Papuan of Maclay Coast marries early, and leads, morally speaking, a most model life, extra-connubial alliances being seldom, or never, formed. The marriage settlements are very simple, the bridegroom making, on agreement with the bride's family, a few presents, such as dishes and dyed cloths. A few days after, a pig or a dog is slain, the marriage feast is celebrated, and the young man takes his bride off to his hut. There is a much simpler procedure, the event being marked by no feast, when a man divorces his wife because she is unable to work, perhaps on account of lameness, for he simply sends her off and takes another. In other respects the men treat their wives well, for it is very seldom that a wife is beaten! The women, however, do all the hard work and carry heavy burdens, so that the freshness and healthiness of youth soon passes away. The children are very cheerful, and seldom scream. They are more petted by the father than by the mother, and Maclay has actually seen, what is very uncommon among savages, toys, in the shape of model canoes, and a kind of top. They, however, in childhood learn all the pursuits of manhood, and early accompany their father into the plantations or on his fishing excursions. It is a comical, though not uncommon sight, to see a boy of four years old gravely tend the fire, fetch wood, clean the dishes, help his father to peel fruit, and then, on the entrance of his mother, run to her and begin to take the breast. The women suckle for far too long a time, which, more than even overwork, is the cause of their having such small families. The day of the Papuan begins with the early dawn, and he loves the crow of the cock which heralds the approach of day. Even it he has nothing particular to do, off he goes to the shore, while it is yet dusk, enveloped in his mal, and with chattering teeth awaits the sunrise. When his wife is already off to the plantation, he lingers over his breakfast, and then either chews betel or smokes a green cigar. About ten o'clock the men depart to their various occupations; and if a visit be paid to a village at noon, not a human being will be seen, but a dog or a pig or two will come out and inspect the intruder, and then disappear again. About four or five in the afternoon the men return, dripping from their daily bath. In spite of numerous skin diseases the Papuans can scarcely be termed dirty, for they daily, often several times a day, take a bath and rub their skin with sand or grass. Later on in the evening come their wives, sweating and staggering under their heavy burdens. Supper is then made ready. Into the pot-au-feut are emptied the most incongruous food stuffs, reminding us almost of the "ingredients" of the witches" caldron in "Macbeth," e.g. beetles, snails, crabs, caterpillars, and small lizards! On these collocasia or dioscorea are put, and over all water, a third part being sea-water, is poured, and the pot, covered with green leaves, is then set on the fire to boil. When all is ready, the master of the house distributes the portions, the worst morsels to his wife and children, reserving the best for himself and his guests. In order to obtain a soupcor of saline flavour, the brine is drunk in which the food was cooked. After a cigar or a quantum of betel, the men retire to rest, previously taking care to light a fire under their bedsteads. So passes away the day of the Papuan, varied only by an occasional excursion, or a feast, or a preparation for war. 